一様曲げ（流れ方向曲げ）を受ける段ボールの弾性強度と形状（第 3 報）* 上下同質のクラフト・ライナーおよび中芯よりなる複両面段ボール

帝人製機株式会社松山工場 松島理 愛媛大学名誉教授 松 島 成 夫

\title{
Relation between Elastic Strength and Shape for Corrugated Fiberboard under Uniform Bending in Moment Axis Perpendicular to Machine Direction (III) On Double Wall Corrugated Fiberborad with Same Kraftliners and Corrugated Mediums in Upper and Lower Sides
}

\author{
Satoru Matsushima \\ Teijin Seiki Corporation, Matsuyama \\ Shigeo Matsushima \\ Hornorary Professor, Ehime University
}

An elastic stress analysis formulation for the double wall corrugated fiberboard (DWCF) with same kraftliners (KLs) and corrugated mediums (CMs) in upper and lower sides was made by simple treatment method corresponding to the deformation of the DWCF structure under uniform bending of the moment axis perpendicular to the machine direction. Then from this formation, the stress analysis for several DWCFs was performed and relations between stresses and shapes of DWCF elements were discussed in detail.

Absolute maximum stresses $\sigma_{\text {kimax }}(i=1,2)$ of upper and lower side KLs are on outer and absolute maximum stresses $\sigma_{\mathrm{s} j \max }(\mathrm{j}=1,2)$ of $\mathrm{CMs}$ are on inner surfaces respectively. $\sigma_{\mathrm{k} i \max }$ increases slightly with the wavelength of $\mathrm{CMs}$ and $\sigma_{\mathrm{s} \text { max }}$ decreases obviously with the wavehight. $\sigma_{\mathrm{k} i \max }$ and $\sigma_{\mathrm{s} \text { max }}$ increase obviously with the thickness and the longitudinal elastic modulus of KLs. And $\sigma_{\mathrm{k} \text { max }}$ increases slightly with the thickness and the longitudinal elastic modulus of CMs but $\sigma_{\text {sjmax }}$ increases obviously.

Keywords : Coputational Mechanics, Structure Analysis, Elastic Bending, Strength of Corrugated Fiberboard, Elastic Stress Analysis, Structure Strength, Numerical Analysis

\section{1. 緒言}

段ボール(1)2 は，構造物についての適用性および生 举性の高い形状をし，高い実用性と有用性をもち，ま

*第2 報：紙ハ技協誌，51（9），1356１365（1997）
た軽量で, 緩衝性に優れているため, 力学的強度を要 する構造性创装材として広く用いられている。そして, 軽量で高い強度形状を有することにより, 段ボール構 造の航空機体（筒形段ボール状）への適用に関する研 究3)がある。したがって, 段ボールのクラフト・ライ ナー (KL)，中芯 (SCP medium) の変形に関する 
力学的強度を基本的に明らかにし, 段ボールに関する 設計強度を確かにすることは，材料工学上，構造工学 上意義あるものと考えられる。

段ボール45)および段ボール箱㫙-8)の強度等に関する 実用的研究は既に行われ，最近においても高い適用性 への要求として,この種の研究がおこなわれている ${ }^{9110)} 。$ なお，段ボールの反り ${ }^{11}$ に関する研究も行われている。

基礎的研究として, 幾何学的条件を基にした段ボー ルの引張り変形強度機構についての実験的研究があ る ${ }^{12)}$ 。弾性論による基礎的研究については, 波板の曲 げ剛性に関する研究 ${ }^{13)}$, 面圧を受ける段ボール中 芯 ${ }^{14115)}$ および波板 ${ }^{15) 16)}$ の内部応力等に関する研究があ る。さらに，接合部の強度に関するものとして，厚さ 方向の引き離し力についての強度 ${ }^{1718)}$, 流れ方向のず れ力についての強度 ${ }^{19)-21)}$ の研究がある。

曲げモーメント軸が流れ方向にある曲げ（縦曲げ）

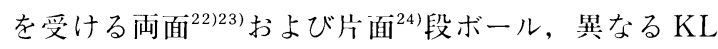
をもつ雨面 ${ }^{25}$ および複両面 ${ }^{26}$ 段ボールに関する弾性曲 げ強度の研究がある。曲げモーメント軸が流れ方向に 直角な向きにある際の曲げ（流れ方向曲げ）強度に関 する基礎的研究として, 同材7728) および異材 ${ }^{30 / 31)}$ の KL をもつ両面段ボールについてのものがある。

包装材として用いられている段ボールの使用状況を みると, 精密機器およびコンピューターの书場の增加 に伴って, 複両面段ボールおよび複々両面段ボールの 利用が非常に盛んである。その使用時の状態をみると, 変形状況は縦曲げばかりではなく, 流れ方向曲げも同 様に多く生じている。したがって, 複両面段ボールの 流れ方向曲げに関する研究をおこなうことは段ボール 下:学上重要なことである。

複両面段ボールの流れ方向曲げに関する基礎的研究 は㕌さ方向に対称に配位する上下同材の KL および 中芯を段ボールについてのものがある ${ }^{31}$ 。この研究は, KL と中芯の配置が厚さ方向および流れ方向に対し対 称的になったものに限定されたものであり, 応力表示 の導出が主なもので, 応力状況の議論は概略である。

そこで, 本報では, 前報 ${ }^{14)-311}$ にならい, 複両面段 ボールの両表面および上下中芯が各同質, 同形で，中 央 KL の材質, 形状, および上下中芯の配置は任意 である際の流れ方向一様曲げを受ける複両面段ボール の㐫力の算定法を導き，これによって段ボール素材の 㐫力值を求め, 本段ボール強度と形状の関係をより詳 細に明らかにすることを試みた。ただし，中芯の形状 を前報の処分にならって，近似的に，正弦波形である とし，構成素材が弾性体であるとした。

\section{2. 解析方法}

一様な流れ方向曲げを受ける両面段ボール27)-30)の 接合部に生じる厚さ方向の荷重は, 近似的に, 零であ ることが示され，また上下同材の $\mathrm{KL}$ およ゙中芯よ りなり，KL・中芯接合部が左右対称に配位した複両 面段ボール ${ }^{31)}$ の厚さ方向の荷重も，近似的に，零であ ることが示されている。これらのことより，流れ方们 一様曲げにおける段ボールの $\mathrm{KL}$ ・中芯接合部の厚さ 方向の荷重は，非常に小さい值であると考えられる。 そこで，上下同材の KL および中芯よりなる複再面 段ボールの KL・中芯接合部の厚さ方向の荷重は, 近 似的に，零であると考える。

複両面段ボールは上下表面 $\mathrm{KL}\left(\mathrm{KL}_{\mathrm{i}} \mathrm{i} \mathrm{i}=1,2\right)$ ， 中央 $\mathrm{KL}\left(\mathrm{KL}_{0}\right)$ および $\mathrm{KL}_{0}$ をはさむ上卜中芯 $\left(\mathrm{CM}_{\mathrm{j}}\right.$

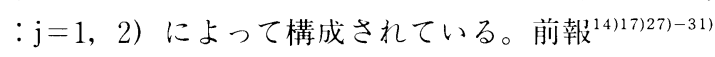
にならい, 中芯の波形を, 近似的に, 正弦波状である と考え， $\mathrm{CM}_{1}$ および $\mathrm{CM}_{2}$ の波高 $\mathrm{h}$ および厚さの中央 の位置を原点 $\left(\mathrm{O}_{1}, \mathrm{O}_{2}\right)$ に拈き，流れ方向（加工方 向）の位置を各 $\mathrm{x}_{1}, \mathrm{x}_{2}$ で, 波形の高さ方向の位置を 各 $\mathrm{y}_{1}, \mathrm{y}_{2}$ で示す (図 1 参照)。そして，それらの方向 に直角な方向を $\mathrm{z}$ 方向にする。なお $\mathrm{KL}_{0} \cdot \mathrm{CM}_{1}$ 接 合部と $\mathrm{KL}_{0} \cdot \mathrm{CM}_{2}$ 接合部との $\mathrm{x}$ 方向の開き $\left(\mathrm{O}_{1}, \mathrm{O}_{2}\right.$ の距離）を $\Delta \mathrm{L}$ ，中芯の波長を $\mathrm{L} て ゙$ 示すと，ト下の $\mathrm{KL}$ ・中芯接合部の $\mathrm{x}$ 方向の位置は任意であるため,

一般に， $\Delta \mathrm{L} \neq 0$ であると考えられる (図 2 参照)。

$\mathrm{CM}_{1}, \mathrm{CM}_{2}$ の厚さ $\left(\mathrm{T}_{\mathrm{s}}\right)$ 中心の位置 $\mathrm{x}_{01}, \mathrm{y}_{01}$ 打よ び $\mathrm{x}_{02}, \mathrm{y}_{02}$ から厚さ方向に $\mathrm{t}_{1}, \mathrm{t}_{2}$ の距離にある位置 $\mathrm{y}_{1}$, $\mathrm{y}_{2}$ は, 近似的に, 各

$$
\begin{aligned}
& y_{0 j}=\left(\frac{h}{2}\right) \sin \left(\frac{2 \pi x_{j}}{L}\right) \quad(j=1,2) \\
& y_{j}=y_{0 j}+t_{j} \cos \theta_{j} \quad(j=1,2)
\end{aligned}
$$

で表される。ただし， $\theta_{1}, \theta_{2}$ は $\mathrm{y}_{01}, \mathrm{y}_{02}$ の接線のうj向 とx方向とのなす角

$$
\theta_{\mathrm{j}}=\tan ^{-1}\left(\frac{\mathrm{dy}_{0 \mathrm{j}}}{\mathrm{dx}_{\mathrm{j}}}\right) \quad(\mathrm{j}=1,2)
$$

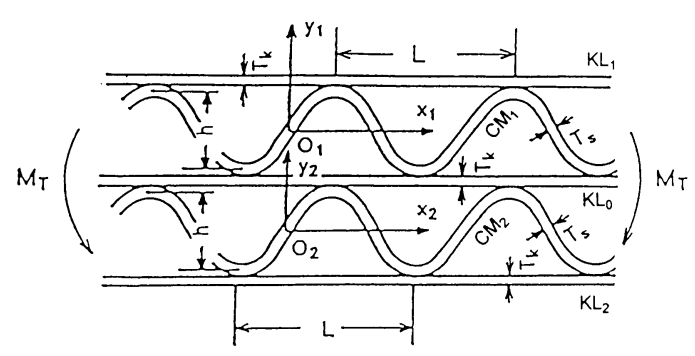

Fig. 1 Bending moment $\mathrm{M}_{\mathrm{T}}$ and coordinates. 


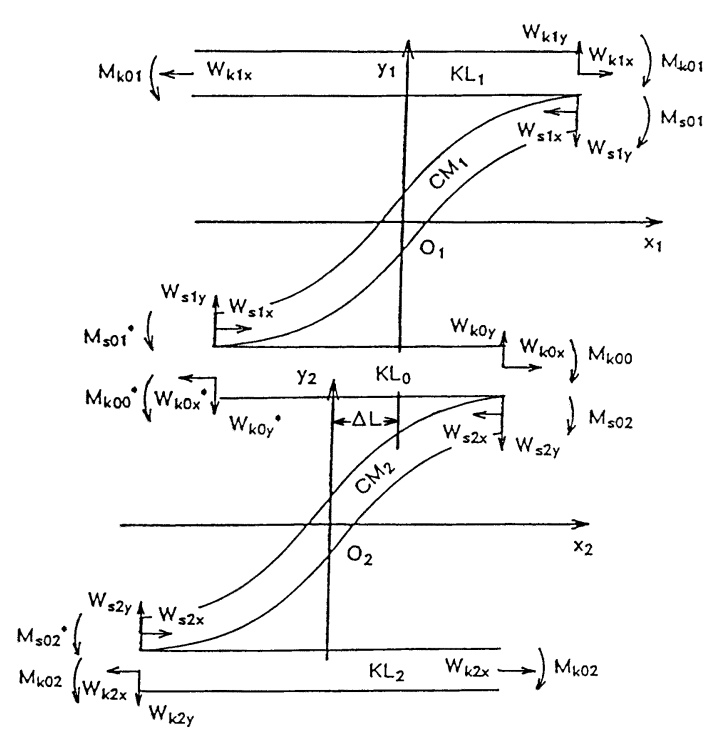

Fig. 2 Actions of joints.

である。

段ボールは広い板状のものであるため, 流れ方向の 微笑な曲げ变形は, $\mathrm{xy}$ 面上に生じ, $\mathrm{z}$ 方向の変異が 零であると考えられ，前報の流れ方向曲げの際 ${ }^{31)}$ と同 様に，平面ひずみ変形であると考えられる。そして， 平面ひずみと平面応力との類似性 ${ }^{32)}$ により，前報 ${ }^{31)}$ と 同様に, 近似的に, KL および中芯の変形は単位幅を もつはりの変形と同様なものであると考える。すなわ ち, 近似的に, $\mathrm{KL}_{1}$ の変形は, $\mathrm{x}=-\mathrm{L} / 2 \sim \mathrm{L} / 2$ の域 で考えれば, $\mathrm{KL}_{1} \cdot \mathrm{CM}_{1}$ 接合部に $\mathrm{x}$ 方向の集中荷重 $\mathrm{W}_{\mathrm{k} 1 \mathrm{x}}$ および固定モーメント $\mathrm{M}_{\mathrm{k} 01}$ の作用力が働く真直 部材はり（段ボール中立面から所定の距離 $\mathrm{Y}_{0}$ にある 部材はり), $\mathrm{KL}_{2}$ の変形は, $\mathrm{KL}_{2} \cdot \mathrm{CM}_{2}$ 接合部に $\mathrm{W}_{\mathrm{k} 2 \mathrm{x}}$ および $\mathrm{M}_{\mathrm{k} 02}$ の作用力が㗢く真值部材はりと同様 なものであると考える（図 2 参照：上述の設定により 接合部 $\mathrm{y}$ 方向の荷重は $\left.\mathrm{W}_{\mathrm{kiy}}=\mathrm{W}_{\mathrm{sjy}}=0\right)$ 。そして, $\mathrm{K}$ $\mathrm{L}_{0}$ の変形は, $\mathrm{KL}_{0} \cdot \mathrm{CM}_{1}$ 接合部に $\mathrm{W}_{\mathrm{kox}}{ }^{*}$ および $\mathrm{M}_{\mathrm{k} 00}$ *の作用力が働き, $\mathrm{KL}_{0} \cdot \mathrm{CM}_{2}$ 接合部に $\mathrm{W}_{\mathrm{kox}}$ お よび $\mathrm{M}_{\mathrm{k} 00}$ の作用力が働く真直部材はりであると考え る。 $\mathrm{CM}_{1}$ については, $\mathrm{KL}_{1} \cdot \mathrm{CM}_{1}$ 接合部に $\mathrm{W}_{\mathrm{s} 1 \mathrm{x}}$, $\mathrm{W}_{\mathrm{s} 1 y}$ および $\mathrm{M}_{\mathrm{s} 01}$ の作用力が㗢き, $\mathrm{CM}_{2}$ については $\mathrm{KL}_{2} \cdot \mathrm{CM}_{2}$ 接合部に $\mathrm{W}_{\mathrm{s} 2 \mathrm{x}}$ および $\mathrm{M}_{\mathrm{s} 02}$ の作用力が働 く曲がりはりであると考える。また, 段ボールの一様 曲げすなわち単位幅当たりの接合部を通る断面に働く モーメント $\mathrm{M}_{\mathrm{T}}$ の一定性により, 着目位置 $\mathrm{x}_{1}, \mathrm{x}_{2}$ $\left(=\mathrm{x}_{1}\right)$ における $\mathrm{M}_{\mathrm{T}}$ は, その位置に働く $\mathrm{KL}_{1}, \mathrm{KL}_{2}$, $\mathrm{KL}_{0}, \mathrm{CM}_{1}, \mathrm{CM}_{2}$ のモーメント $\mathrm{M}_{\mathrm{k} 1}, \mathrm{M}_{\mathrm{k} 2}, \mathrm{M}_{\mathrm{k} 0}, \mathrm{M}_{\mathrm{s} 1}$, $\mathrm{M}_{\mathrm{s} 2}$ の和

$$
\mathrm{M}_{\mathrm{T}}=\mathrm{M}_{\mathrm{k} 1}+\mathrm{M}_{\mathrm{k} 2}+\mathrm{M}_{\mathrm{k} 0}+\mathrm{M}_{\mathrm{s} 1}+\mathrm{M}_{\mathrm{s} 2}
$$
で表される。段ボールの作用力がモーメント $\mathrm{M}_{\mathrm{T}}$ のみ で外力は零であることにより, 結合部の幾何学的条件 および力の釣合い条件を考虑すると, $\mathrm{KL}_{1}, \mathrm{KL}_{2}$ およ び $\mathrm{KL}_{0}$ については各

$$
\begin{gathered}
\mathrm{W}_{\mathrm{kix}}=\mathrm{W}_{\mathrm{sjx}} \quad \mathrm{W}_{\mathrm{kox}}{ }^{*}=\mathrm{W}_{\mathrm{sjx}} \\
(\mathrm{i}=1,2: \mathrm{j}=1,2)
\end{gathered}
$$

であるものと考えられ，対称性を考虑すると， $\mathrm{x}_{\mathrm{j}}=$ $-\mathrm{L} / 4 \sim \mathrm{L} / 4$ 域側の $\mathrm{M}_{\mathrm{k} 01}, \mathrm{~W}_{\mathrm{k} 1 \mathrm{x}}, \mathrm{M}_{\mathrm{s} 01}, \mathrm{~W}_{\mathrm{s} 1 \mathrm{x}}$ などの 全ての作用力は $\mathrm{x}=\mathrm{L} / 4 \sim 3 \mathrm{~L} / 4$ 域側のものと等しい ものと考えられる。そして, $\mathrm{KL}_{0}$ の $\mathrm{W}_{\mathrm{s} 1 \mathrm{x}}$ および $\mathrm{W}_{\mathrm{s} 2 \mathrm{x}}$ の働きによる変形は, 曲げと単純, 一様な $\mathrm{W}_{\mathrm{s} 1 \mathrm{x}}$ および $\mathrm{W}_{\mathrm{s} 2 \mathrm{x}}$ による引張り，圧縮との重合わせである と考えられる。

\subsection{KL の変形について}

$\mathrm{KL}_{1}$ の $\mathrm{x}_{1}$ における $\mathrm{M}_{\mathrm{k} 1}$ および $\mathrm{KL}_{2}$ の $\mathrm{x}_{2}$ における $\mathrm{M}_{\mathrm{k} 2}$ は, $-\mathrm{L} / 4<\mathrm{x}_{1}<\mathrm{L} / 4$ および $-\mathrm{L} / 4<\mathrm{x}_{2}<\mathrm{L} / 4$ で

$$
\mathrm{M}_{\mathrm{ki}}=\mathrm{M}_{\mathrm{k} 0 \mathrm{i}} \quad(\mathrm{i}=1,2)
$$

$\mathrm{KL}_{0}$ の $\mathrm{x}$ 方向の位置 $\mathrm{x}_{0}$ の基点を $\mathrm{x}_{1}=-\mathrm{L} / 4$ に，すな わち

$$
\mathrm{x}_{0}\left(\mathrm{x}_{1}=-\mathrm{L} / 4\right)=0
$$

にすると, $\mathrm{x}_{0}$ および $\mathrm{x}_{0}=\mathrm{L} / 2+\Delta \mathrm{L}$ の $\mathrm{KL}_{0}$ の $\mathrm{CM}_{1}$ お よび $\mathrm{CM}_{2}$ 接合部の固定モーメントが $\mathrm{M}_{\mathrm{k} 00}{ }^{*}, \mathrm{M}_{\mathrm{k} 00}$ で あることより， $\mathrm{KL}_{0}$ におけるモーメント $\mathrm{M}_{\mathrm{k} 0}$ は， $\mathrm{x}_{0}$ $=0$ の際, 近似的に,

$$
\mathrm{M}_{\mathrm{k} 0}=\mathrm{M}_{\mathrm{k} 00}
$$

$\mathrm{x}_{0}=\mathrm{L} / 2+\Delta \mathrm{L}$ の際

$$
\mathrm{M}_{\mathrm{k} 0}=\mathrm{M}_{\mathrm{k} 00}{ }^{*}
$$

で表される。

$\mathrm{KL}_{1}$ 表面から段ボールの中立面までの距離を $\mathrm{Y}_{0}$ で 示すと, 真直はりの曲げ応力の算定によって, 中立面 からの距離 $\mathrm{Y} の$ 位置にある $\mathrm{KL}_{1}, \mathrm{KL}_{2}$ および $\mathrm{KL}_{0} の$ 曲げ応力 $\sigma_{\mathrm{k} 1}, \sigma_{\mathrm{k} 2}$ および $\sigma_{\mathrm{k} 0}$ は, 近似的に

$$
\begin{aligned}
& \sigma_{\mathrm{ki}}=\frac{\mathrm{M}_{\mathrm{ki}} \mathrm{Y}}{\mathrm{I}_{\mathrm{k} 1}}+\frac{\mathrm{W}_{\mathrm{kix}}}{\mathrm{T}_{\mathrm{k}}} \quad(\mathrm{i}=1,2) \\
& \sigma_{\mathrm{k} 0}=\frac{\mathrm{M}_{\mathrm{k} 0} \mathrm{Y}}{\mathrm{I}_{\mathrm{k} 0}}+\frac{\mathrm{W}_{\mathrm{k} 0 \mathrm{x}}}{\mathrm{T}_{\mathrm{k} 0}} \\
& \mathrm{~W}_{\mathrm{k} 0 \mathrm{x}}=\mathrm{W}_{\mathrm{k} 1 \mathrm{x}}+\mathrm{W}_{\mathrm{k} 2 \mathrm{x}}
\end{aligned}
$$

で表される33)34)。ただし， $\mathrm{I}_{\mathrm{k} 1}, \mathrm{I}_{\mathrm{k} 2}$ および $\mathrm{I}_{\mathrm{k} 0}$ は $\mathrm{KL}_{1}$ ， $\mathrm{KL}_{2}$ および $\mathrm{KL}_{0}$ の 2 次断面係数

$$
\begin{aligned}
& \mathrm{I}_{\mathrm{k} 1}=\mathrm{I}_{\mathrm{k}}+\left(\mathrm{Y}_{0}+\frac{\mathrm{T}_{\mathrm{k}}}{2}\right)^{2} \mathrm{~T}_{\mathrm{k}} \\
& \mathrm{I}_{\mathrm{k}}=\mathrm{T}_{\mathrm{k}}{ }^{3} / 12 \\
& \mathrm{I}_{\mathrm{k} 2}=\mathrm{I}_{\mathrm{k}}+\left(\mathrm{T}_{\mathrm{T}}-\mathrm{Y}_{0}-\frac{\mathrm{T}_{\mathrm{k}}}{2}\right) \mathrm{T}_{\mathrm{k}} \\
& \mathrm{T}_{\mathrm{T}}=2 \mathrm{~T}_{\mathrm{k}}+\mathrm{T}_{\mathrm{k} 0}+2 \mathrm{~T}_{\mathrm{s}}+2 \mathrm{~h}
\end{aligned}
$$




$$
\begin{aligned}
& \mathrm{I}_{\mathrm{k} 0}=\mathrm{I}_{\mathrm{k} 00}+\left(\mathrm{Y}_{0}-\frac{\mathrm{T}_{\mathrm{k} 0}}{2}\right) \mathrm{T}_{\mathrm{k} 0} \\
& \mathrm{I}_{\mathrm{k} 00}=\mathrm{T}_{\mathrm{k} 0}{ }^{3} / 12
\end{aligned}
$$

であり， $\mathrm{T}_{\mathrm{k}}$ は $\mathrm{KL}_{1}, \mathrm{KL}_{2}, \mathrm{~T}_{\mathrm{k} 0}$ は $\mathrm{KL}_{0}$ の厚さである。

$\mathrm{KL}_{1}$ および $\mathrm{KL}_{2}$ の $\mathrm{x}$ おび $\mathrm{y}$ 方向の変位 $\delta_{\mathrm{kx} 1}$, $\delta_{\mathrm{kx} 2}$ および $\delta_{\mathrm{ky} 1}, \delta_{\mathrm{ky} 2}$ は各

$$
\begin{aligned}
& \delta_{\mathrm{k} x \mathrm{i}}=\frac{\mathrm{L}}{2 \mathrm{E}_{\mathrm{k}}}+\frac{\mathrm{L}_{\mathrm{i}} \mathrm{W}_{\mathrm{kix}}}{2 \mathrm{E}_{\mathrm{k}} \mathrm{T}_{\mathrm{k}}} \quad(\mathrm{i}=1,2) \\
& \delta_{\mathrm{k} i \mathrm{y}}=\frac{\mathrm{L}^{2} \mathrm{M}_{\mathrm{k} 0 \mathrm{i}}}{2 \mathrm{E}_{\mathrm{k}}}
\end{aligned}
$$

$\mathrm{KL}_{1}, \mathrm{KL}_{2}$ および $\mathrm{KL}_{0}$ の $\mathrm{x}$ 方向に対する傾き $\mathrm{i}_{\mathrm{k} 1}, \mathrm{i}_{\mathrm{k} 2}$ および $\mathrm{i}_{\mathrm{k} 0}$ は各

$$
\begin{aligned}
& \mathrm{i}_{\mathrm{ki}}=\frac{\mathrm{M}_{\mathrm{k} 0 \mathrm{i}}}{2 \mathrm{E}_{\mathrm{ki}} \mathrm{I}_{\mathrm{ki}}} \quad(\mathrm{i}=1,2) \\
& \mathrm{i}_{\mathrm{k} 0}=\frac{\mathrm{M}_{\mathrm{k} 00} \mathrm{~L}}{2 \mathrm{E}_{\mathrm{k} 0} \mathrm{I}_{\mathrm{k} 0}}
\end{aligned}
$$

で表される。ただし， $\mathrm{E}_{\mathrm{k}}$ は $\mathrm{KL}_{1}$ の縦弾性係数である。

\section{2 中芯の変形について}

$\mathrm{CM}_{1}$ および $\mathrm{CM}_{2}$ の位置 $\mathrm{x}_{1}$ および $\mathrm{x}_{2}$ におけるモー メント $\mathrm{M}_{\mathrm{s} 1}$ および $\mathrm{M}_{\mathrm{s} 2}$ は

$$
\mathrm{M}_{\mathrm{sj}}=\mathrm{M}_{\mathrm{sj}}-\mathrm{W}_{\mathrm{sjx}}\left(\frac{\mathrm{h}_{\mathrm{j}}}{2}-\mathrm{y}_{0 \mathrm{j}}\right) \quad(\mathrm{j}=1,2)
$$

曲がりはりの応力表示にしたがって $\mathrm{CM}_{1}$ および $\mathrm{CM}_{2}$ の $\mathrm{x}_{1}, \mathrm{y}_{1}$ および $\mathrm{x}_{2}, \mathrm{y}_{2}$ における曲げ応力 $\sigma_{\mathrm{s} 1}$ および $\theta_{\mathrm{s} 2}$ は

$$
\begin{gathered}
\sigma_{\mathrm{sj}}=\frac{N_{\mathrm{sj}}}{\mathrm{T}_{\mathrm{sj}}}+\frac{M_{\mathrm{sj}}}{\mathrm{T}_{\mathrm{sj} \rho_{\mathrm{j}}}}\left[1+\frac{1}{\mathrm{k}_{\mathrm{j}}} \frac{\mathrm{t}_{\mathrm{j}}}{\left(\rho_{\mathrm{j}}+\mathrm{t}_{\mathrm{j}}\right)}\right] \\
(\mathrm{j}=1,2)
\end{gathered}
$$

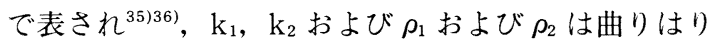
の断面係数および曲率半径

$$
\begin{aligned}
k_{j}= & \frac{1}{3}\left(\frac{T_{s j}}{2 \rho_{j}}\right)^{2}+\frac{1}{5}\left(\frac{T_{s j}}{2 \rho_{j}}\right)^{4}+\frac{1}{7}\left(\frac{T_{s j}}{2 \rho_{j}}\right)^{6}+\cdots \cdots \\
& (j=1,2) \\
\rho_{j}=- & {\left[1+\left(\frac{d y_{0 j}}{d x_{j}}\right)^{2}\right]^{3 / 2}\left(\frac{d^{2} y_{0 j}}{d_{x_{j}}^{2}}\right)^{-1} } \\
& (j=1,2)
\end{aligned}
$$

$\mathrm{N}_{\mathrm{s} 1}$ および $\mathrm{N}_{\mathrm{s} 2}$ は $\mathrm{CM}_{1}$ および $\mathrm{CM}_{2}$ の軸力

$$
\mathrm{N}_{\mathrm{sj}}=-\mathrm{W}_{\mathrm{sjx}} \cos \theta_{\mathrm{j}} \quad(\mathrm{j}=1,2)
$$

である。ただし， $T_{\mathrm{s}}$ は中芯の厚さである。

$\mathrm{CM}_{1}$ および $\mathrm{CM}_{2}$ の着目位置とその曲率半径の中心 とを通る直線と $\mathrm{x}$ 方向とのなす角を $\phi_{1}$ および $\phi_{2}$

$$
\phi_{\mathrm{j}}=\pi / 2-\theta_{\mathrm{j}} \quad(\mathrm{j}=1,2) \quad \cdots \cdots(16)
$$

とし，それらの変化より $\mathrm{CM}_{1}$ および $\mathrm{CM}_{2}$ の $\mathrm{x}, \mathrm{y}$ 方 向の変位 $\sigma_{\mathrm{sx} 1}, \sigma_{\mathrm{sy} 1}$ および $\delta_{\mathrm{sx} 2}, \delta_{\mathrm{sy} 2}$ を求める既知の
法 ${ }^{37)}$ を用い，応力の算定をおこなう。

$$
\text { この法によると, } \delta_{\mathrm{sx} 1}, \delta_{\mathrm{sx} 2} お よ ひ ゙ \delta_{\mathrm{sy} 1}, \delta_{\mathrm{sy} 2} \text { は }
$$

$$
\begin{gathered}
\delta_{\mathrm{sxj}}=-\frac{1}{E_{\mathrm{s}} T_{\mathrm{s}}} \int_{-\mathrm{L} / 4}^{\mathrm{L} / 4}\left[\mathrm{~N}_{\mathrm{sj}}+\frac{\mathrm{M}_{\mathrm{sj}}\left(1+\mathrm{k}_{\mathrm{j}}\right)}{\rho_{\mathrm{j}}}\right] \\
{\left[\frac{\mathrm{h}_{\mathrm{j}}}{2}-\mathrm{y}_{0 \mathrm{j}}\right] \mathrm{d} \phi_{\mathrm{j}} \quad(\mathrm{j}=1,2)}
\end{gathered}
$$

$$
\begin{array}{r}
\delta_{\mathrm{s} y \mathrm{j}}=\frac{-1}{\mathrm{E}_{\mathrm{s}} T_{\mathrm{s}}} \int_{-\mathrm{L} / 4}^{\mathrm{L} / 4}\left[\mathrm{~N}_{\mathrm{sj}}+\frac{\mathrm{M}_{\mathrm{sj}}\left(1+\mathrm{k}_{\mathrm{j}}\right)}{\rho_{\mathrm{j}}}\right] \\
{\left[\frac{\mathrm{L}_{\mathrm{j}}}{4}-\mathrm{x}_{\mathrm{j}}\right] \mathrm{d} \phi_{\mathrm{j}} \quad(\mathrm{j}=1,2)}
\end{array}
$$

で表され，たわみ角 $\mathrm{i}_{\mathrm{s} 1}$ および $\mathrm{i}_{\mathrm{s} 2}$ は

$$
\begin{gathered}
\mathrm{i}_{\mathrm{s}}=-\frac{1}{E_{\mathrm{s}} \mathrm{T}_{\mathrm{s}}} \int_{-\mathrm{L} / 4}^{\mathrm{L} / 4}\left[\mathrm{~N}_{\mathrm{sj}}+\frac{\mathrm{M}_{\mathrm{sj}}\left(1+\mathrm{k}_{\mathrm{j}}\right)}{\rho_{\mathrm{j}}}\right] \mathrm{d} \phi_{\mathrm{j}} \\
(\mathrm{j}=1,2)
\end{gathered}
$$

で表される。ただし， Es は中芯の縦弾性係数である。

\section{3. 未定値の決定について}

(8 a )，(8b）および(13)より KL および中芯の応力 を求めるには, 作用力 $\mathrm{W}_{\mathrm{k} 1 \mathrm{x}}, \mathrm{W}_{\mathrm{k} 2 \mathrm{x}}$ ならびに $\mathrm{M}_{\mathrm{k} 01}, \mathrm{M}_{\mathrm{k} 02}$, $\mathrm{M}_{\mathrm{k} 00}$ および $\mathrm{M}_{\mathrm{s} 01}, \mathrm{M}_{\mathrm{s} 02}$ などの值を明らかにする必要 がある。そこで, これらの值の決定について議論する。

実際に使われる段ボールの大きさは，L, h に比べ 非常に大きなものである。そして, $\mathrm{KL}_{1}$ と $\mathrm{KL}_{2}$ とが, また $\mathrm{CM}_{1}$ と $\mathrm{CM}_{2}$ とが各同材であるために, $\mathrm{KL} ・$ 中 芯接合部の変位状態は一様な板と同様になるものと考 えられる。すなわち, 本変形は一様曲げであるため, 段ボール各位置の総モーメント $\mathrm{M}_{\mathrm{T}}$ は等しく, 各接合 部の変形は等しい值をとるものと考之られ，その位置 の $\mathrm{KL}_{1}, \mathrm{KL}_{2}$ の傾きは, 近似的に, 等しいものと考 えられ, $\mathrm{x}_{\mathrm{j}}=-\mathrm{L} / 4 \sim \mathrm{L} / 4$ 間に生じる $\mathrm{KL}_{1}, \mathrm{KL}_{2}$ の傾 き $\mathrm{i}_{\mathrm{k} 1}, \mathrm{i}_{\mathrm{k} 2}$ およびたわみ $\delta_{\mathrm{ky} 1}, \delta_{\mathrm{ky} 2}$ も等しく,

$$
\mathrm{i}_{\mathrm{k} 1}=\mathrm{i}_{\mathrm{k} 2} \quad \delta_{\mathrm{k} y 1}=\delta_{\mathrm{k} y 2} \quad \cdots \cdots(19 \mathrm{a})
$$

になるものと考えられる。また，(6)，(7 a ），(7 b) お よび幾何学的条件により, $\mathrm{KL}_{0}$ の傾き $\mathrm{i}_{\mathrm{k} 0}$ も, 近似的に,

$$
\mathrm{i}_{\mathrm{k} 0}=\mathrm{i}_{\mathrm{k} 1}
$$

であるものと考えられる。

曲げに伴う中芯の変形は, 上述のように，曲がりは りと同様な変形を示すものとすれば，その変化は複雑 になるものと考えられる。しかし，近似的に，はりの 曲げ理論によると，純曲げに伴う伸びは L に比べ非 常に小さいものと考之られ, 中芯のhの変化も非常 に小さいものと考えられる。一方, 中芯の引つ張りお よび圧縮による伸びおよび縮み変形は，その大きさが, 近似的に，同様なものであると考えられる。すると， 
段ボールの純曲げは各部材に大きさの等しい単純な引 つ張り，圧縮变形が部材曲げに加わったものであると 考えられる。このことにより， $\mathrm{KL}_{1}$ と $\mathrm{KL}_{2}$ ，および $\mathrm{CM}_{1}, \mathrm{CM}_{2}$ が各同質および同形であるために中立軸は, 近似的に，段ボールの厚さ中央にあり，Y０は

$$
\mathrm{Y}_{0}=\mathrm{T}_{\mathrm{T}} / 2
$$

となり，(9a)，(9b）より上下 $\mathrm{KL}$ および中芯の反 射性変形強度により $I_{k 1}$ および $I_{k 2}$ は

$I_{\mathrm{k} 1}=\mathrm{I}_{\mathrm{k} 2}$

で表せる。そして，(6)，(11 a)，(19a）より，関係

$\mathrm{M}_{\mathrm{k} 01}=\mathrm{M}_{\mathrm{k} 02}=\left(\mathrm{E}_{\mathrm{k} 1} \mathrm{I}_{\mathrm{k} 1} / \mathrm{E}_{\mathrm{k} 0} \mathrm{I}_{\mathrm{k} 0}\right) \mathrm{M}_{\mathrm{k} 00}$

が成り立つことがわかる。接合部で，関倸

$$
\mathrm{i}_{\mathrm{k} i}=\mathrm{i}_{\mathrm{sj}} \quad(\mathrm{i}=\mathrm{j}=1,2)
$$

が成り立つことおよび（17 a)，(17b)，(18)より，近 似的に, $\mathrm{M}_{\mathrm{s} 01}$ および $\mathrm{M}_{\mathrm{s} 02}$ は

$$
\mathrm{M}_{\mathrm{s} 01}=\mathrm{M}_{\mathrm{s} 02}
$$

で表せる。

(4)および(22)，(24)より関係

$$
\begin{aligned}
& \mathrm{M}_{\mathrm{s} 01}=(1 / 2)\left(\mathrm{M}_{\mathrm{T}}-\mathrm{A}_{\mathrm{B}} \mathrm{M}_{\mathrm{k} 01}\right) \\
& \mathrm{A}_{\mathrm{B}}=\left[2+\mathrm{E}_{\mathrm{k} 0} \mathrm{I}_{\mathrm{k} 0} / \mathrm{E}_{\mathrm{k} 1} \mathrm{I}_{\mathrm{k} 1}\right]
\end{aligned}
$$

$\mathrm{KL}_{1}$ と $\mathrm{CM}_{1}$ との $\mathrm{i}_{1}$ が等しいことおよび（11 a)，(18) より関係

$$
\begin{aligned}
& -\frac{W_{\text {six }}}{E_{\mathrm{s}} T_{\mathrm{s}}} \int_{x=-L / 4}^{x=L / 4} B_{1}\left(\frac{h}{2}-y_{0}\right) d \phi_{1} \\
& +\frac{M_{\mathrm{s} 01}}{E_{\mathrm{s}} T_{\mathrm{s}}} \int_{x=-\mathrm{L} / 4}^{x=L / 4} B_{1} \mathrm{~d} \phi_{1}=\frac{\mathrm{LM}_{\mathrm{k} 01}}{2 \mathrm{E}_{\mathrm{k}} T_{\mathrm{k} 1}} \\
& \mathrm{~B}_{1}=\frac{1+\mathrm{k}_{1}}{\rho_{1} \mathrm{k}_{1}}
\end{aligned}
$$

が得られる。

幾何学的条件より，(10 a）拈よび（17 a）の $\delta_{\mathrm{s} 1 \mathrm{x}}$ および $\delta_{k 1 x}$ が等しいものと考えられ，関係

$$
\begin{aligned}
& -\frac{1}{\mathrm{E}_{\mathrm{s}} \mathrm{T}_{\mathrm{s}}}\left(\mathrm{A}^{*}+\mathrm{B}^{*}\right) \mathrm{W}_{\mathrm{s} 1 \mathrm{x}}+\mathrm{A}^{* *} \mathrm{M}_{\mathrm{s} 01} \\
& =\frac{L M_{k 01}}{2 E_{k} I_{k}}\left(Y_{0}-\frac{T_{k}}{2 T}\right)+\frac{L W_{T}}{2 E_{k} T_{k}} \\
& \mathrm{~A}^{*}=\int_{\mathrm{x}=-\mathrm{L} . / 4}^{\mathrm{x}=\mathrm{L} / \mathrm{4}}\left(\frac{\mathrm{h}}{2}-\mathrm{y}_{01}\right) \sin \phi_{1} \mathrm{~d} \phi_{1} \\
& A^{* *}=\int_{x=-L / 4}^{x=L / 4} B_{1}\left(\frac{h}{2}-y_{01}\right) d \phi_{1} \\
& B^{*}=\int_{x=-1 / 4}^{x=1 . / 4} B_{1}\left(\frac{h}{2}-y_{01}\right)^{2} d \phi_{1}
\end{aligned}
$$

が得られる。これより， $\mathrm{W}_{\mathrm{s} 01}, \mathrm{M}_{\mathrm{s} 01}, \mathrm{M}_{\mathrm{k} 01}$ は

$$
\begin{aligned}
& \mathrm{W}_{\mathrm{s} 01}=\mathrm{D}_{1} / \mathrm{D}_{\mathrm{T}} \\
& \mathrm{M}_{\mathrm{s} 01}=\mathrm{D}_{2} / \mathrm{D}_{\mathrm{T}} \\
& \mathrm{M}_{\mathrm{k} 01}=\mathrm{D}_{3} / \mathrm{D}_{\mathrm{T}}
\end{aligned}
$$

で表されることがわかる。ただし， $\mathrm{D}_{\mathrm{T}}, \mathrm{D}_{1}, \mathrm{D}_{2}, \mathrm{D}_{3}$ は

$$
\begin{aligned}
D_{\mathrm{T}}=\left|\begin{array}{lll}
\mathrm{A}_{1} & \mathrm{~B}_{11} & \mathrm{C}_{1} \\
\mathrm{~A}_{2} & \mathrm{~B}_{2} & \mathrm{C}_{2} \\
\mathrm{~A}_{3} & \mathrm{~B}_{3} & \mathrm{C}_{3}
\end{array}\right| & \mathrm{D}_{1}=\left|\begin{array}{lll}
\mathrm{D}_{1} & \mathrm{~B}_{11} & \mathrm{C}_{1} \\
\mathrm{D}_{2} & \mathrm{~B}_{2} & \mathrm{C}_{2} \\
\mathrm{D}_{3} & \mathrm{~B}_{3} & \mathrm{C}_{3}
\end{array}\right| \\
D_{2}=\left|\begin{array}{lll}
\mathrm{A}_{1} & \mathrm{D}_{1} & \mathrm{C}_{1} \\
\mathrm{~A}_{2} & \mathrm{D}_{2} & \mathrm{C}_{2} \\
\mathrm{~A}_{3} & \mathrm{D}_{3} & \mathrm{C}_{3}
\end{array}\right| & \mathrm{D}_{3}=\left|\begin{array}{lll}
\mathrm{A}_{1} & \mathrm{~B}_{11} & \mathrm{D}_{1} \\
\mathrm{~A}_{2} & \mathrm{~B}_{2} & \mathrm{D}_{2} \\
\mathrm{~A}_{3} & \mathrm{~B}_{3} & \mathrm{D}_{3}
\end{array}\right|
\end{aligned}
$$

$\mathrm{A}_{1}, \mathrm{~B}_{11}, \mathrm{C}_{1}, \cdots \cdots \mathrm{B}_{3}, \mathrm{C}_{3}, \mathrm{D}_{3}$ は

$$
\mathrm{A}_{1}=0 \quad \mathrm{~B}_{11}=1 \quad \mathrm{C}_{1}=1 / 2 \quad \mathrm{D}_{1}=\mathrm{A}_{\mathrm{B}} / 2
$$

$\mathrm{A}_{2}=\frac{\mathrm{A}^{* *}}{\mathrm{E}_{\mathrm{s}} \mathrm{T}_{\mathrm{s}}} \quad \mathrm{B}_{2}=\frac{\mathrm{M}_{\mathrm{s} 01}}{\mathrm{E}_{\mathrm{s}} \mathrm{T}_{\mathrm{s}}} \int_{\mathrm{x}=-\mathrm{L} / 4}^{\mathrm{x}=\mathrm{L} / 4} \mathrm{~B}_{1} \mathrm{~d} \phi_{1}$

$\mathrm{C}_{2}=\mathrm{L} /\left(2 \mathrm{I}_{\mathrm{k} 1}\right) \quad \mathrm{D}_{2}=0$

$\mathrm{A}_{3}=-\left[\mathrm{A}^{*}+\mathrm{B}^{*}-\mathrm{L} / 2\right] /\left(\mathrm{E}_{\mathrm{k}} \mathrm{T}_{\mathrm{k}}\right)$

$\mathrm{B}_{3}=\mathrm{A}^{* *} /\left(\mathrm{E}_{\mathrm{k}} \mathrm{T}_{\mathrm{k}}\right)$

$$
\mathrm{C}_{3}=\mathrm{L}\left(\mathrm{Y}_{0}-\mathrm{T}_{\mathrm{k}} / 2\right) /\left(2 \mathrm{E}_{\mathrm{k}} \mathrm{I}_{\mathrm{k} 1}\right) \quad \mathrm{D}_{3}=0
$$

である。

(28 a) より $\mathrm{W}_{\mathrm{s} 01}$ を, (28 b) より $\mathrm{M}_{\mathrm{s} 01}\left(=\mathrm{M}_{\mathrm{s} 02}\right)$ を, (28 c) より $\mathrm{M}_{\mathrm{k} 01}$ を明らかにすれば，(13)によって曲げ 㐫力 $\sigma_{\mathrm{s} 1} ， \sigma_{\mathrm{s} 2}$ の值を求めることができ，(27)より $\mathrm{M}_{\mathrm{k} 01}$ $\left(=\mathrm{M}_{\mathrm{k} 02}\right)$ を明らかにすれば，（8 a ）抢よび（8 b ）に よって $\sigma_{\mathrm{k} 1}, \sigma_{\mathrm{k} 2}$ 抢よび $\sigma_{\mathrm{k} 0}$ の值を求めることができる。

以上のように, 本表示は, $\mathrm{KL}_{1}$ と $\mathrm{KL}_{0}$ とが異質, 異形で, $\mathrm{KL}$ ・中芯接合部の流れ方向の位置自由なも のについての表示の導出をおこなったものであるが, $\mathrm{KL}_{1}, \mathrm{KL}_{0}$ が同質，同形であれば，表示の值は前報 ${ }^{31)}$ のものと同様になることが伺えた。

\section{4. 解析結果と考察}

本解析に用いた複両面段ボール材の形状は, 実用段 ボールの形状 (Aフルート+Aフルート， B フルー ト $+\mathrm{B}$ フルート $)^{38 / 39)}$, 素材科量 ${ }^{40141)}$ を考虑し, $\mathrm{T}_{\mathrm{s}}=$ $0.24 \mathrm{~mm}, \mathrm{~h}=4.6 \mathrm{~mm}, \mathrm{~L}=9.2 \mathrm{~mm}, \mathrm{~T}_{\mathrm{k}}=0.60 \mathrm{~mm}$, $\mathrm{T}_{\mathrm{k} 0}=0.30 \mathrm{~mm}$ および $\mathrm{T}_{\mathrm{s}}=0.24 \mathrm{~mm}, \mathrm{~h}=2.3 \mathrm{~mm}, \mathrm{~L}$ $=4.6 \mathrm{~mm}, \mathrm{~T}_{\mathrm{k}}=0.30 \mathrm{~mm}, \mathrm{~T}_{\mathrm{k} 0}=0.30 \mathrm{~mm}$ のものを, 中心として議論する。そして，KLおよび中芯の縦弾 性係数は近似的に各 $\mathrm{E}_{\mathrm{k}}=5.8 \times 10^{3} \mathrm{~N} / \mathrm{mm}^{2}{ }^{42)}\left(=\mathrm{E}_{\mathrm{k} 0}\right)$ および $\mathrm{E}_{\mathrm{s}}=2.8 \times 10^{3} \mathrm{~N} / \mathrm{mm}^{2}{ }^{23)}$ であるが，便宜上， $\mathrm{E}_{\mathrm{k}}=2 \mathrm{~N} / \mathrm{mm}^{2}, \mathrm{E}_{\mathrm{s}}=1 \mathrm{~N} / \mathrm{mm}^{2}$ であるとし，また， $\mathrm{M}_{\mathrm{T}}$ を単位化し， $\mathrm{M}_{\mathrm{T}}=1 \mathrm{~N}$ として，計算処理をする。 計算時, 角增分の積分処理は角差分法を用い, 積分䛊 差 $1 \%$ 程度以下の分割数 $\mathrm{N}=10^{4}$ でおこない, 以下の ように，曲げ応力状況を議論する。

(8 a)，(8 b) および(13)によって，KL $\mathrm{KL}_{1}, \mathrm{KL}_{2}, \mathrm{KL}_{0}$ および $\mathrm{CM}_{1}, \mathrm{CM}_{2}$ の曲げ応力 $\sigma_{\mathrm{k}}$ 拈よび $\sigma_{\mathrm{S}}$ の值を求め, 
これらの值と $\mathrm{x}_{\mathrm{i}}, \mathrm{x}_{\mathrm{j}}$ および $\mathrm{t}_{\mathrm{i}}, \mathrm{t}_{\mathrm{j}}$ との関係 $(\mathrm{i}=0,1$, $2: \mathrm{j}=1,2)$ を図3 $(\mathrm{a}, \mathrm{b})$ および図 $4(\mathrm{a}, \mathrm{b})$ に亦す。

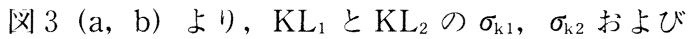
$\mathrm{CM}_{1}$ および $\mathrm{CM}_{2}$ の $\sigma_{\mathrm{s} 1}, \sigma_{\mathrm{s} 2}$ の絶対佃は共に等しい変 化を亦すことがわかる。 $\mathrm{KL}_{1}, \mathrm{KL}_{2}$ および $\mathrm{KL}_{0}$ の $\sigma_{\mathrm{k} 1}$, $\sigma_{\mathrm{k} 2}$ および $\sigma_{\mathrm{k} 0}$ は $\mathrm{x}_{\mathrm{i}}$ の増減によらず一定になることが, $\mathrm{t}_{\mathrm{j}}\left(=\mathrm{T}_{\mathrm{s}} / 2\right)>0$ では, $\mathrm{x}_{\mathrm{j}}$ の増加によって, $\mathrm{CM}_{1}$ は負值 から正値に, $\mathrm{CM}_{2}$ は正値から負值に大きく変化する ことがわかる。

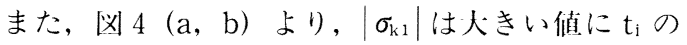
增加に伴う比例的な増加が, $\left|\sigma_{\mathrm{k} 0}\right|$ は, 小さい値では あるが, $\mathrm{t}_{0}$ の増加に伴う正比例的な増減が見受けられ る。そして, $\left|\sigma_{\mathrm{si}}\right|$ は $\mathrm{t}_{\mathrm{j}}$ の増加に伴ってほほ比例的に 増減することがわかる。

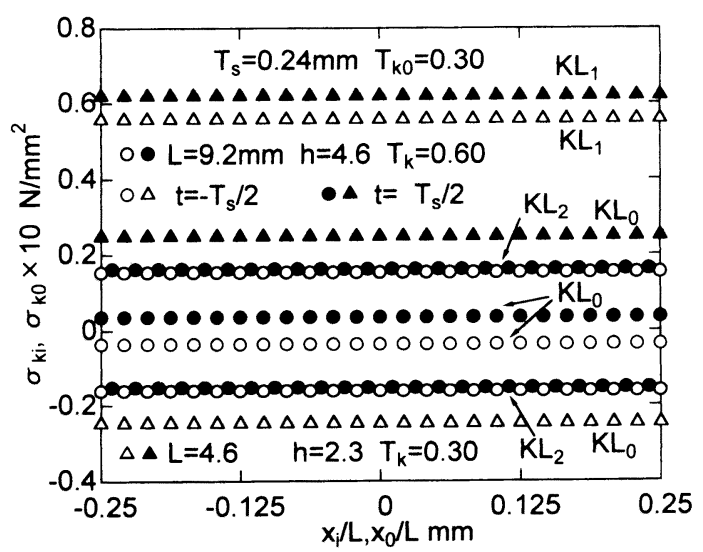

(a)

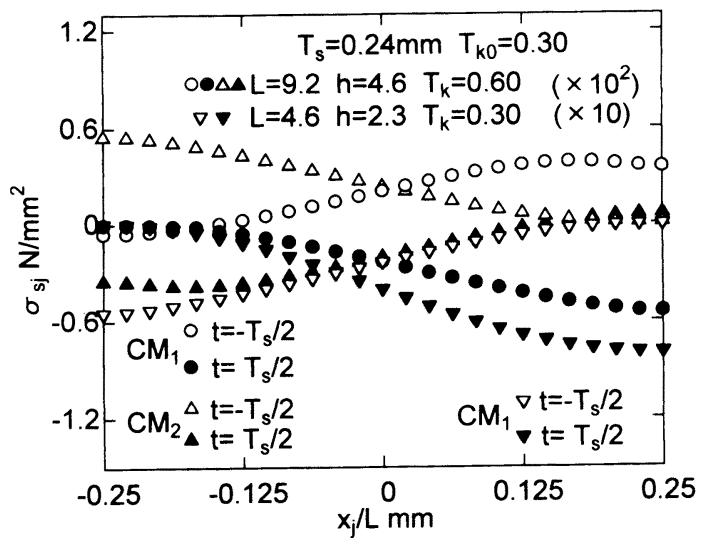

(b)

Fig.3 Bending stresses and positions $\mathrm{x}_{\mathrm{i}} \quad(\mathrm{i}=1$, 2), $x_{j}(j=1,2)$.

$\mathrm{E}_{\mathrm{k}}=\mathrm{E}_{\mathrm{k} 0}=2 \mathrm{~N} / \mathrm{mm}^{2}$ and $\mathrm{E}_{\mathrm{s}}=1 \mathrm{~N} / \mathrm{mm}^{2}$.

(a) Stress patterns for KLs. (b) Stress patterns for CMs. $\sigma_{\mathrm{k} 1}$ および $\sigma_{\mathrm{k} 2}$ の絶対値の最大值は段ボールのトト $\mathrm{KL}$ の外表面にあり，|$\sigma_{\mathrm{k} 0} \mid$ の最大值は $\mathrm{KL}_{0}$ の屾表消

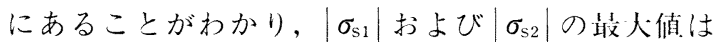
$\mathrm{KL}$ ・中芯接合部の内表面（たとえば， $\mathrm{CM}_{1}$ では $\mathrm{x}_{1}$ $\left.=\mathrm{L} / 4, \mathrm{t}_{1}=-\mathrm{T}_{\mathrm{s}} / 2\right)$ に特じることがわかる。

本変形状態の特徵として，流れうj向曲げを受ける陑 面段ボール中芯の曲げ応力の最大值が $\mathrm{KL}$ ・中芯接合 部の内側表面に生じるのと同様に, $\left|\sigma_{\mathrm{s} 1}\right|$ および $\left|\sigma_{\mathrm{s} 2}\right|$ の最大值は内表面に牛じるが，流れう们曲げを受ける 両上ト同材の KLおよび中芯よりなる複両段ボール の流れ方向曲げでは，一般に，その絶対值が外表面の 值より，顕著に大きい。そして，内表面の曲げ㐫力の 最大值は上下が逆符号の值を示すようになり，本段ボ 一ル中芯の変形は各中芯の純曲げに，伸び，斤濰が加

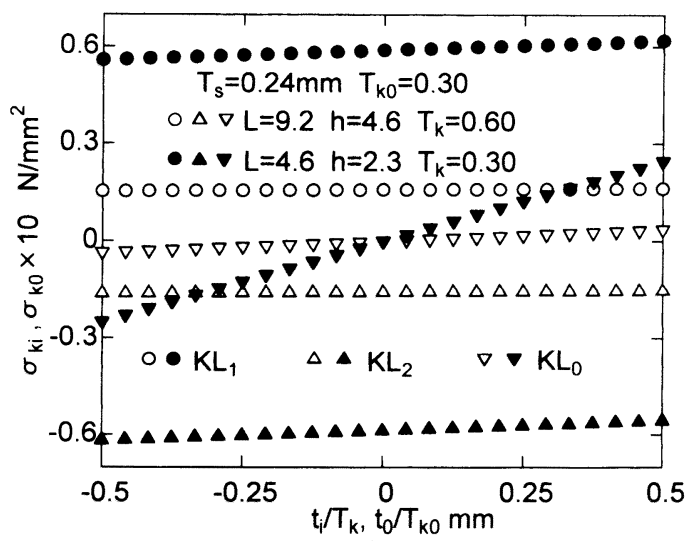

(a)

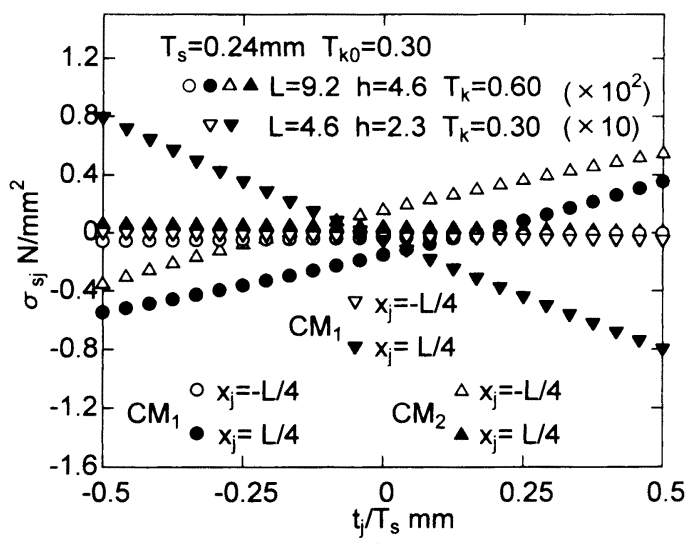

(b)

Fig.4 Bending stresses and positions $t_{i} \quad(i=1$, 2), $t_{j}(j=1,2)$. $\mathrm{E}_{\mathrm{k}}=\mathrm{E}_{\mathrm{k} 0}=2 \mathrm{~N} / \mathrm{mm}^{2}$ and $\mathrm{E}_{\mathrm{s}}=1 \mathrm{~N} / \mathrm{mm}^{2}$. (a) Stress patterns for KLs. (b) Stress patterns for CMs. 
わったものであることを考慮すると，このような変形 は，曲げ変形によって生じる上側の中芯の変形には相 当大きい伸びが，下側には相当大きい圧縮が加わり生 じたものと考えられる。

構造部材の破壊は，一般に，最大応力位置の個所か ら生じているものと考えられ，その応力值は形状およ び材質によって大きく変化するものと考えられる。

そこで, 各構成部材の最大応力と形状との関係を議 論する。

求めた $\mathrm{KL}_{1}, \mathrm{KL}_{2}, \mathrm{KL}_{0}$ の最大応力の最大值 $\sigma_{\mathrm{k} 1 \max }$, $\sigma_{\mathrm{k} 2 \max }\left(=\sigma_{\mathrm{k} 1 \max }\right), \quad \sigma_{\mathrm{k} 0 \max }$ と $\mathrm{L}$ との関係および $\mathrm{CM}_{1}$, $\mathrm{CM}_{2}$ の最大応力の最大值 $\sigma_{\mathrm{s} 1 \max }, \sigma_{\mathrm{s} 2 \max }\left(=\sigma_{\mathrm{s} 1 \max }\right)$

と L との関係を図 5 に示す。

図より，Lの増加によって， $\sigma_{\mathrm{k} 1 \max } ， \sigma_{\mathrm{k} 0 \max }$ は緩や かに減少することがわかる。しかし， $\sigma_{\mathrm{s} 1 \max }$ は， $\mathrm{x}=$ $\mathrm{L} / 4$ 付近の無限大の値から急激に減少し, その後, 緩 やかな增加を示す。

$\mathrm{L}$ の増加による各 $\mathrm{KL}$ 材および $\mathrm{x}_{\mathrm{j}}=\mathrm{L} / 2$ 付近の中 芯の応力無限大からの減少は, (13)より, $1 /\left(\rho_{\mathrm{j}}-\mathrm{t}_{\mathrm{j}} / 2\right)$ の項の寄与によるものと考えられ，中芯素材の減少に 伴う強度減少を考虑すると， $\sigma_{\mathrm{s} 1 \max }$ の緩やかな増加は Lの増加による中芯素材の減少に伴う強度低下による ものと考えられる。

$\sigma_{\mathrm{k} 1 \max }, \sigma_{\mathrm{k} 0 \max }$ とh $\mathrm{h}$ との関係および $\sigma_{\mathrm{s} 1 \max }$ と $\mathrm{h}$ との 関係を図 6 に示す。

困より, hの増加によって, $\sigma_{\mathrm{k} 1 \max }, \sigma_{\mathrm{k} 0 \max }, \sigma_{\mathrm{s} 1 \max }$ は顕著に減少することがわかる。

な拀，hの増加による最大応力の大きな低下は，(8 a）抒よび (9a)，(9b) より，hの増加による断面 2

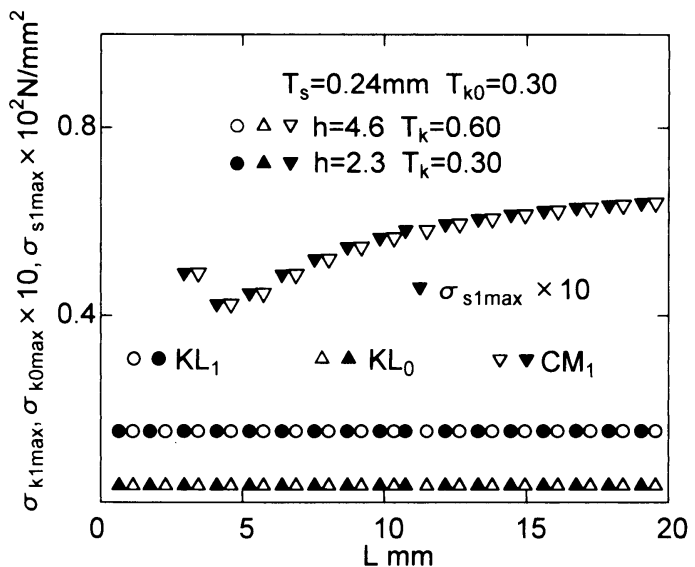

Fig.5 Relations between maximum stresses and $\mathrm{L}$.

$\mathrm{E}_{\mathrm{k}}=\mathrm{E}_{\mathrm{k} 0}=2 \mathrm{~N} / \mathrm{mm}^{2}$ and $\mathrm{E}_{\mathrm{s}}=1 \mathrm{~N} / \mathrm{mm}^{2}$.
次モーメントの大きな増加によって生じるものと考え られる。

$\sigma_{\mathrm{k} 1 \max } ， \sigma_{\mathrm{k} 0 \max }$ および $\sigma_{\mathrm{s} 1 \max }$ と $\mathrm{T}_{\mathrm{k}}$ および $\mathrm{E}_{\mathrm{k}}$ との関 係を図 7 に示す。

困より， $\mathrm{T}_{\mathrm{k}}$ および $\mathrm{E}_{\mathrm{k}}$ の増加によって， $\sigma_{\mathrm{k} 1 \text { max }}$, $\sigma_{\mathrm{k} 0 \max }$ および $\sigma_{\mathrm{s} \text { max }}$ は顕著に減少することがわかる。

$\mathrm{T}_{\mathrm{k}}$ および $\mathrm{E}_{\mathrm{k}}$ の増加による $\mathrm{KL}$ の最大応力の顕著 な減少は，(8a)，(8b)，(9a)，(9b) および (11a)， (11 b) より， $\mathrm{T}_{\mathrm{k}}$ および $\mathrm{E}_{\mathrm{k}}$ の増加による断面 2 次モ ーメントおよびこわさの顕著な増加によって，中芯の 低下は顕著な断面 2 次モーメントの增加，段ボールの

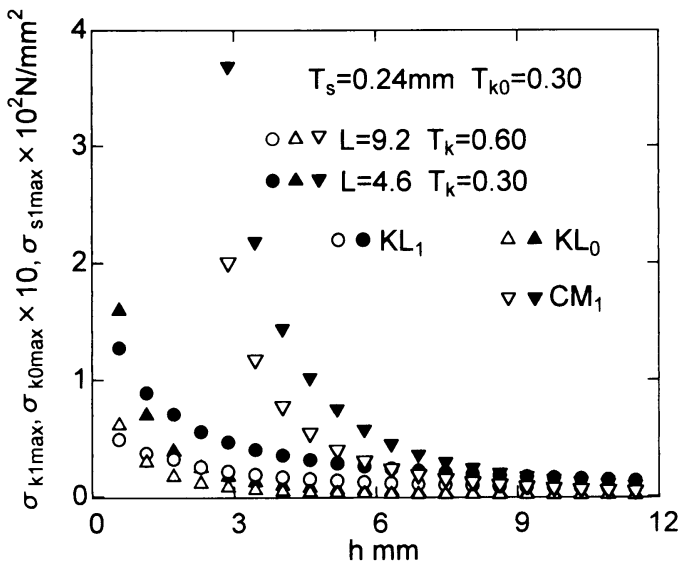

Fig.6 Relations between maximum stresses and h.

$\mathrm{E}_{\mathrm{k}}=\mathrm{E}_{\mathrm{k} 0}=2 \mathrm{~N} / \mathrm{mm}^{2}$ and $\mathrm{E}_{\mathrm{s}}=1 \mathrm{~N} / \mathrm{mm}^{2}$.

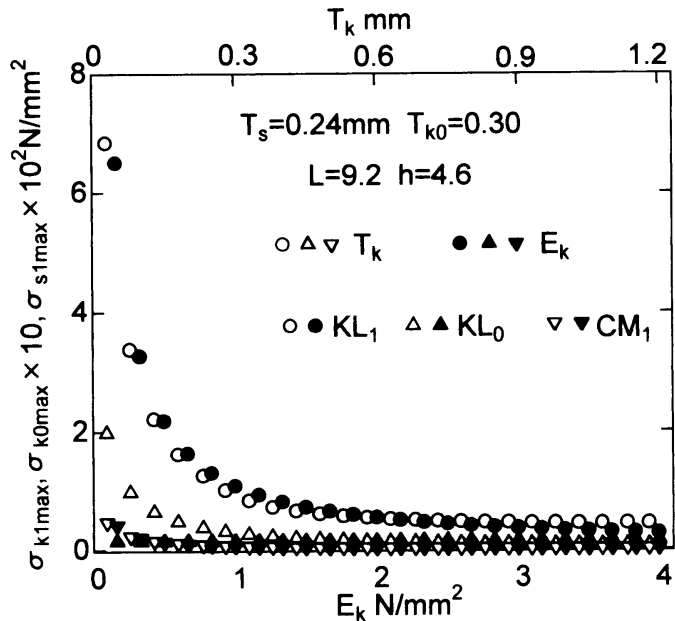

Fig.7 Relations between maximum stresses, $T_{k}$ and $\mathrm{E}_{\mathrm{k}}$.

$E_{k 0}=2 \mathrm{~N} / \mathrm{mm}^{2}$ and $E_{\mathrm{s}}=1 \mathrm{~N} / \mathrm{mm}^{2}$. 


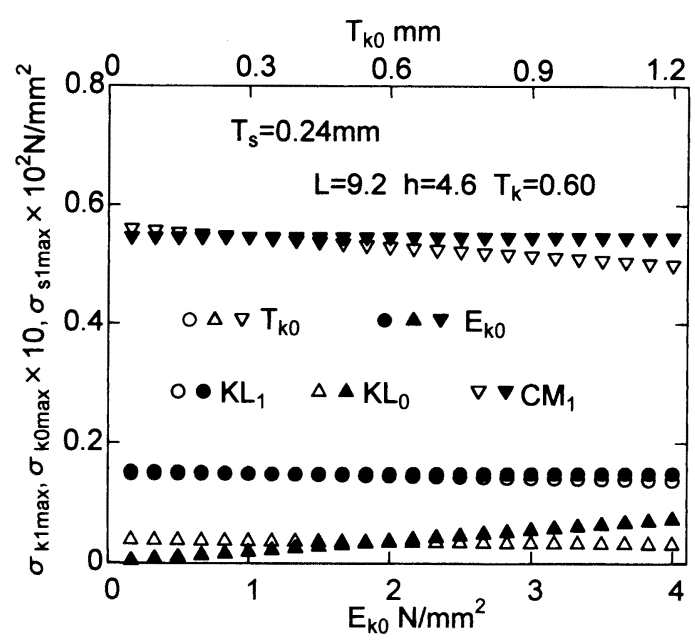

Fig.8 Relations between maximum stresses, $\mathrm{T}_{\mathrm{k} 0}$ and $\mathrm{E}_{\mathrm{k} 0}$.

$\mathrm{E}_{\mathrm{k}}=2 \mathrm{~N} / \mathrm{mm}^{2}$ and $\mathrm{E}_{\mathrm{s}}=1 \mathrm{~N} / \mathrm{mm}^{2}$.

強度増加により生じたものと考えられる。

$\sigma_{\mathrm{k} 1 \max }, \sigma_{\mathrm{k} 0 \max }$ および $\sigma_{\mathrm{s} 1 \max }$ と $\mathrm{T}_{\mathrm{k} 0}$ および $\mathrm{E}_{\mathrm{k} 0}$ との 関係を図 8 に示す。

図より， $T_{\mathrm{k} 0}$ の増加によって $\sigma_{\mathrm{k} 0 \mathrm{max}}$ は緩やかに減少 するが， $\mathrm{E}_{\mathrm{k} 0}$ の増加によって顕著に増加することがわ かる。そして, $\mathrm{T}_{\mathrm{k} 0}$ および $\mathrm{E}_{\mathrm{k} 0}$ の増加によって, $\sigma_{\mathrm{k} 1 \max }$ および $\sigma_{\mathrm{s} 1 \max }$ は緩やかに減少することがわかる。

$\mathrm{T}_{\mathrm{k} 0}$ および $\mathrm{E}_{\mathrm{k} 0}$ の増加による上下 $\mathrm{KL}$ およ゙中芯の 最大応力の緩やかな減少は, 素材の強度減少を考虑す ると, $\mathrm{T}_{\mathrm{k} 0}$ の増加による $\mathrm{KL}_{0}$ 素材の増加に伴う強度 增加によるものと考えられ, 上下中芯の最大応力の緩 やかな減少は, (13)より， $\mathrm{T}_{\mathrm{k} 0}$ および $\mathrm{E}_{\mathrm{k} 0}$ の増加による 中芯の変形抵抗の増加に基づく $\mathrm{M}_{\mathrm{k} 00}$ の増加, $\sigma_{\mathrm{s} 0}$ の 増加によって生じるものと考えられる。 $\mathrm{T}_{\mathrm{k} 0}$ および $\mathrm{E}_{\mathrm{k} 0}$ による $\sigma_{\mathrm{k} 0 \max }$ の増加は $\mathrm{T}_{\mathrm{k} 0}$ および $\mathrm{E}_{\mathrm{k} 0}$ によって $\mathrm{KL}_{0}$ の変形抵抗が增加し， $\mathrm{M}_{\mathrm{k} 0}$ が増加したことによ るものと考えられる。

$\sigma_{\mathrm{k} 1 \max }, \sigma_{\mathrm{k} 0 \max } お よ ひ ゙ \sigma_{\mathrm{s} 1 \max }$ と $\mathrm{T}_{\mathrm{s}}$ および $\mathrm{E}_{\mathrm{s}}$ との関 係を図 9 に示す。

四より， $\mathrm{T}_{\mathrm{s}}$ および $\mathrm{E}_{\mathrm{s}}$ の増加によって， $\sigma_{\mathrm{k} 1 \max }$, $\sigma_{\mathrm{k} 0 \max }$ は緩やかに減少し， $\sigma_{\mathrm{s} 1 \max }$ は $\mathrm{T}_{\mathrm{s}}$ の增加によっ て顕著に増加するが, $\mathrm{E}_{\mathrm{s}}$ の増加によって緩やかに増 加することがわかる。

$\mathrm{T}_{\mathrm{s}} お よ ひ ゙ \mathrm{E}_{\mathrm{s}}$ の増加による各 $\mathrm{KL}$ の最大応力の䌅や かな減少は, 全 $\mathrm{KL}$ 材の強度減少を考虑すると, $\mathrm{T}_{\mathrm{s}}$ および $\mathrm{E}_{\mathrm{s}}$ の増加に基づく中芯素材の増加に伴う強度 低下によるものと考えられ，(17 a ），(17b)，(18)より $\mathrm{T}_{\mathrm{s}}$ および $\mathrm{E}_{\mathrm{s}}$ の増加に伴う $\sigma_{\mathrm{s} 1 \mathrm{max}}$ の増加は $\mathrm{T}_{\mathrm{s}}$ および

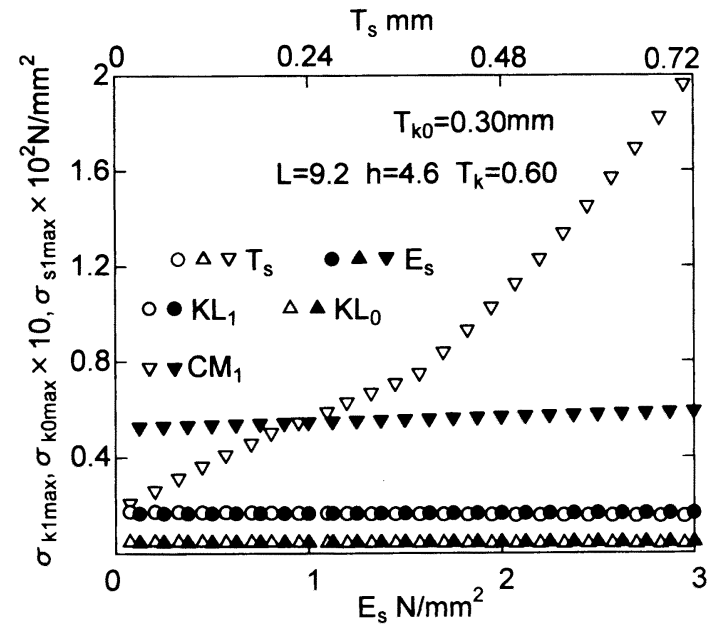

Fig.9 Relations between maximum stresses, $T_{s}$ and $\mathrm{E}_{\mathrm{s}}$.

$\mathrm{E}_{\mathrm{k}}=\mathrm{E}_{\mathrm{k} 0}=2 \mathrm{~N} / \mathrm{mm}^{2}$.

$\mathrm{E}_{\mathrm{s}}$ の増加に基づく中芯の変形抵抗の増加によって $\mathrm{KL}$ 中芯接合部の固定モーメント $\mathrm{M}_{\mathrm{s} 0 \mathrm{i}}$ の増加が生じ たことによるものと考えられる。

以上のことより, 曲げ変形時の段ボール構造の高い 強度保持への寄与はいくつかの要因があると思われる が，主なるものは，KLの間隔保持と中芯の横変位の 阻止にあるものと考えられる。すなわち,この阻止に よって, 曲げ変形時, 常に, $\mathrm{KL}_{1}, \mathrm{KL}_{0}, \mathrm{KL}_{2}$ の各間 隔が一定となる状態が保たれ, 高い強度状態を亦す幾 何学的保持にあるものと考えられる。

\section{5. 結言}

両表面同材の KLをもつ複両面段ボールに一様曲 げが働く際の段ボール各素材の応力と形状との関係を 明らかにするなめに，計算処理容易な解析表示の導出 を試みた。そして，本表示より，KL および中芯の縦 弾性係数を $2 \mathrm{~N} / \mathrm{mm}^{2}$ および $1 \mathrm{~N} / \mathrm{mm}^{2}$ とし，上下の $\mathrm{KL}$ および中芯の厚さ $\mathrm{T}_{\mathrm{k}}=0.30 \mathrm{~mm}, \mathrm{~T}_{\mathrm{k} 0}=0.30 \mathrm{~mm}$, $\mathrm{T}_{\mathrm{s}}=0.24 \mathrm{~mm}$, および中芯の波長 $\mathrm{L}=9.2 \mathrm{~mm}$, 波高 $\mathrm{h}=4.6 \mathrm{~mm}$ の形状を主とした際の複両面段ボールの $\mathrm{KL}$ おび中芯の曲げ応力の值を求め, その強度状海 を議論した。その結果，以下のようなことが明らかに なった。

（1）本段ボールの素材の変形は単純な引張り，王繀 変形と一様曲げ変形との組合せによって表せる。 そして，段ボール表面の KLの最大值は外側表 面に, 内 $\mathrm{KL}$ はその両表面にあり，中芯は $\mathrm{KL}$ ・ 中芯接合部の内表面にある。全素材の最大値は段 
ボール表面の KL 外面にある。

(2) $\mathrm{KL}$ の曲げ応力最大值は中芯波長 L の増加に伴 って緩やかに増加し，中芯の最大值はまず急激に 減少し, やがて緩やかに增加する。各素材の緩や かな增加は L の増加に基づく中芯素材の減少に よって, 中芯に現れる急激な減少は中芯形状の特 異性によって生じる。

（3）段ボール各素材の曲げ応力の最大值は，中芯波 高 hの増加に伴って減少する。このことは, hの 增加に基づく両表面の $\mathrm{KL}$ の断面 2 次モーメン トの増加によって生じるものとみなされた。

(4) 段ボール各素材の曲げ応力の最大值は, 表面 $\mathrm{KL}$ の厚さ $\mathrm{T}_{\mathrm{k}}$ および縦弾性係数 $\mathrm{E}_{\mathrm{k}}$ の増加に伴 って減少する。このことは， $\mathrm{T}_{\mathrm{k}}$ および $\mathrm{E}_{\mathrm{k}}$ の増 加に基づく雨表面の $\mathrm{KL}$ の断面 2 次モーメント およびこわさの増加によって生じるものとみなさ れた。

（5）段ボール表面の KL および中芯の応力の最大 值は，段ボール厚さ中央の $\mathrm{KL}$ の厚さ $\mathrm{T}_{\mathrm{k} 0}$ およ び縦弾性係数 $\mathrm{E}_{\mathrm{k} 0}$ の増加に伴って減少し, 段ボー ル厚さ中央の $\mathrm{KL} は ， \mathrm{E}_{\mathrm{k} 0}$ の増加に伴って減少す るが, $T_{k 0}$ の増加に伴って増加する。この各素材 の減少は， $\mathrm{T}_{\mathrm{k} 0}$ および $\mathrm{E}_{\mathrm{k} 0}$ の增加に基づく両表面 の KLの断面 2 次モーメントおよびこわさの増 加によるものであり, 増加は $\mathrm{T}_{\mathrm{k} 0}$ の増加による 中央の $\mathrm{KL}$ の変形抵抗の増加に基づく $\mathrm{KL}$ ・中芯 接合部の固定モーメント増加に基因するものであ るとみなされた。

(6) 各 KLの応力の最大值は, 中芯の厚さ $\mathrm{T}_{\mathrm{s}}$ およ び縦弾性係数 $\mathrm{E}_{\mathrm{s}}$ の增加に伴って僅か減少し, 中 芯は $T_{\mathrm{s}}$ の增加に伴って緩やかに減少するが, $\mathrm{E}_{\mathrm{s}}$ の増加に伴って顕著に増加する。この各素材の減

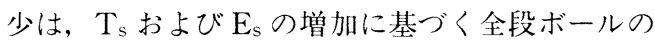
強度増加の奇与によるものであり，中芯の増加は $\mathrm{E}_{\mathrm{s}}$ の増加による中芯の変形抵抗の増加に基づく $\mathrm{KL}$ ・中芯接合部の固定モーメント増加によって 牛じるものとみなされた。

尌算処理に当たり，本表示は，積分途上で，中芯の 曲摔半径㧍よび厚さ中央の接線角の変化に無限大が生 じる。また, 中芯の曲率半径と中芯厚さの半值とが等 しくなる状態での無限大が生じ，関数表示（追記参 照）を用いると, 収斂性が悪く, 積分域分割数 $10^{5}$ で も数倍の数值の变動が生じるが，差分法を用いた接線 角の変化を用いると積分域分割数 10 で $20 \%, 10^{4}$ で 1\%程度の変動誤差が生じ，比較的収斂性がよくなる ことがわかった。このことより，接線角の差持法を用
いた処方を用いて計算処理をおこなった。

本研究は, $\mathrm{KL}$-中芯の流れ方向位置自由で, 上下 同質同形の $\mathrm{KL}$ (中央の $\mathrm{KL}$ とは異材）および中芯よ りなる複両面段ボールの流れ方向曲げの弾性応力に対 し比較的よい精度で変形が議論できる簡易算定法を導 出し, その複兩面段ボールの曲げ強度を議論したもの である。このような段ボールの強度は, 段ボール設計 上重要なことであるが, このような強度表示を求めた ものは見当たらない。したがって, 本結果は, 強度の 設定にあたり，有意義な資料となるものと考えられる。

\section{文献}

1）例えば，段ボール実用百科編集委貪会：段ボール 実用百科，一律書房，21（1970）.

2）レンゴー株式会社：段ボール技術，包装新聞社， 16 (1971).

3）例えば，渋谷：航空学会誌，7 (61)，393 (1940)； 8 (71)，267 (1941)；林：航空学会誌，8 (79), 1131 (1941).

4）例えば，1）のP.537；2）のP.310.

5) Koning J. W. Jr. and Stern R. : Tappi (Tech-nical Association Pulp \& Paper Industry), 60 (12), 128 (1977).

6）例えば，1）の P.548：2）のP.316.

7）例えば, 紙業夕イムス社：新・紙加工便覧, 紙業 タイムス社 797 (1980).

8) Maltenfort G. G. : Tappi, 53 (11), 1076 (1970) ; Grartaganis P.: Tappi, 58 (11), 102 (1975) ; Morris R. M. Jr. and Vallow G. P. : Tappi, 58 (11), 110 (1975).

9）川端洋一：日本包装学会誌，6 (4), 19 (1997).

10）川端洋一：日本包装学会誌，6（4），24（1997）.

11）不㴊・ほか 4 名：議論, 59 (557, A), 156 (1993).

12）松島・ほか 3 名：紙技協誌，36（3），377（1982）。

13) Timoshenko S. P. and Krieger S. W. : Theory of Plates and Shells, McGraw Hill Co., 366 (1959).

14）松島・ほか 2 名：紙八技協誌，42（5）４80（1988）.

15）松島・ほか 2 名：紙技協誌，43（5），602（1989）。

16）松島・ほか 2 名：紙技協誌，44（5），605（1990）.

17）松島・ほか 3 名：紙八技協誌，45（4），480（1991）。

18）松島理・松島：紙八技協誌，50 (4)，707 (1996).

19）松島理・松島：日本包装学会誌，5（3）, 211 (1996).

20）松島理・松島：紙パ技協誌，51（4），645（1997）.

21）松島理・松島：日本包装学会誌，6 (2)，258 (1997). 266.

22）松島理・松島：日本包装学会誌，6（5），258 
(1996).

23）松島・ほか 3 名：紙八技協誌，46（5），668（1992）.

24）松島・ほか 3 名：紙八技協誌，47（4）, 517 (1993).

25）松島・ほか 2 名：紙八技協誌，48（4），600（1994）.

26）松島・ほか 2 名：紙八゚技協誌，49（6）, 956 (1995).

27）松島, 松島：機論, 60 (576, A), 1814 (1994).

28）松島理・松島：紙パ技協誌，50（9），1299（1996）.

29）松島, 松島：機論, 61 (577, A), 1601 (1995).

30）松島理・松島：紙八゚技協誌, 51 (9)，1356（1996）.

31）松島, 松島：機論, 63 (611, A), 1525 (1997).

32）清家；材料力学, 共立出版, 23 (1978).

33）例えば, 黒木：材料力学, 森北出版, 52 (1967).

34) 例えば, 白鳥：材料の力学, 朝倉書店, 69 (1973).

35）例えば, 33）のP.150.

36）例えば，34）のP.95

37）例えば，34）のP.98.
38）例えば，1）の P.64.

39）例えば, 2) のP.264.

40）例えば, 1) のP.115.

41）例えば，2）のP.432.

42) Jones A. R. : Tappi, 51 (5), 203 (1968).

43）例えば，1）の P.126.

\section{追記}

無限大を起こす特異点は(13)の $1 /\left(1-\mathrm{t}_{\mathrm{j}} / \rho_{\mathrm{j}}\right), \quad(14 \mathrm{a})$ の $1 /\left(\mathrm{d}^{2} \mathrm{y}_{0 \mathrm{j}} / \mathrm{dx}_{\mathrm{j}}^{2}\right)$ の項および $(17 \mathrm{a}),(17 \mathrm{~b}),(18) の$ $\mathrm{d} \phi_{\mathrm{j}}$ の值にある。すなわち, $\mathrm{t}_{\mathrm{j}} /\left(1-\mathrm{t}_{\mathrm{j}} / \rho_{\mathrm{j}}\right)$ の項は $\mathrm{t}_{\mathrm{j}}=$ $\rho_{\mathrm{j}}$ で, $1 /\left(\mathrm{d}^{2} \mathrm{y}_{0 \mathrm{j}} / \mathrm{dx}_{\mathrm{j}}^{2}\right)$ の項は $\mathrm{x}_{\mathrm{j}}=0$ で, 正または傎の 無限大となり, $\mathrm{d} \phi_{\mathrm{j}}$ は

$$
\mathrm{d} \phi_{\mathrm{j}}=-\left(\mathrm{d}^{2} \mathrm{y}_{0 \mathrm{j}} / \mathrm{dx}_{\mathrm{j}}{ }^{2}\right) \mathrm{dx}_{\mathrm{j}} /\left[1-\left(\mathrm{dy}_{0 \mathrm{j}} / \mathrm{dx}_{\mathrm{j}}\right)^{2}\right]
$$

で表され, $\mathrm{dy}_{0 \mathrm{j}} / \mathrm{dx}_{\mathrm{j}}= \pm 1$ で正および負の無限大となる。

(受理：'98.2.6) 